\title{
UJI MODEL FISIK RAYAPAN GELOMBANG PADA REVETMEN BUIS BETON
}

\section{PHYSICAL MODELLING TEST OF WAVE RUN-UP ON PRECAST CONCRETE PIPE REVETMENT}

\author{
Juventus Welly R. Ginting1)*, Eduardo Meyrianso Simanjuntak ${ }^{2)}$ \\ Ida Ayu Irawati Diah Ratna Putra ${ }^{3)}$
}

\author{
1)Direktorat Kepatuhan Intern, Direktorat Jenderal Sumber Daya Air, Kementerian PUPR \\ Jalan Pattimura No 20 Kebayoran Baru, DKI Jakarta - Indonesia \\ 2)Program Studi Oseanografi Fakultas Ilmu dan Teknologi Kebumian, Institut Teknologi Bandung, Jalan \\ Ganesha 10 Bandung, Jawa Barat, Indonesia \\ 3)Balai Teknik Pantai, Direktorat Jenderal Sumber Daya Air, Kementerian PUPR \\ Jalan Gilimanuk - Singaraja KM 122, Desa Musi, Kecamatan Gerokgak, Buleleng - Bali - Indonesia \\ *Correspondent email: juventusginting@pu.go.id
}

Diterima: 12 Agustus 2020; Direvisi: 30 Maret 2021; Disetujui: 07 Mei 2021

\begin{abstract}
Buis Beton (Precast concrete pipe) revetment is a common coastal structure to protect the shoreline from erosion. However, it is common that this type of structure face high wave run up. A continuous wave run up on the slope of the structure may reduce the life service of Buis Beton revetment. The objective of this research is to create scientific based guidance to design an efficient Buis Beton revetment against wave run up. A physical modelling test is conducted to understand the relationship between wave run up and Buis Beton revetment. The test scenario is based on the slope of the structure $(\theta)$, structure height (L), buis beton diameter $(\varphi)$, incoming wave height (Hi) and wave period (T). The physical modelling is conducted in 2D wave flume with laboratory scale of 1:10 with regular wave simulation. Wave run up is observed using a video camera which is later processed digitally to acquire the wave run up data. This research shows that the relative wave run up has a reciprocal functional relationship with the Iribarren Number parameter. In general, wave run up height on Buis Beton revetment is less than or equal to 2.64 the wave height, HmO.
\end{abstract}

Keywords: Revetment, buis beton, wave run-up, physical modelling

\begin{abstract}
ABSTRAK
Revetmen Buis Beton merupakan salah satu struktur perlindungan pantai yang umum untuk menanggulangi masalah erosi pantai. Namun, salah satu kendala yang sering ditemukan adalah tingginya rayapan gelombang pada struktur tersebut. Rayapan gelombang yang terjadi secara terus menerus ini mengurangi masa pakai struktur revetmen Buis Beton. Tujuan penelitian ini adalah untuk membuat acuan ilmiah untuk desain revetmen Buis Beton yang efisien dalam mengurangi tinggi rayapan gelombang. Uji model fisik dilakukan untuk memahami hubungan antara rayapan gelombang dengan revetmen Buis Beton. Skenario uji model fisik ini ditentukan berdasarkan kemiringan pada susunan buis beton $(\theta)$, kedalaman muka air (d), ketinggian struktur (L), diameter buis beton $(\varphi)$, gelombang datang (Hi), dan periode gelombang (T). Uji pemodelan fisik ini dilakukan pada saluran gelombang 2D dengan skala laboratorium 1:10 dengan simulasi gelombang reguler. Rayapan gelombang diamati dengan bantuan kamera video yang kemudian diproses secara digital untuk memperoleh data tinggi rayapan gelombang. Hasil penelitian menunjukkan bahwa tinggi rayapan gelombang relatif memiliki hubungan reciprocal terhadap parameter Bilangan Iribarren. Secara umum, tinggi rayapan gelombang pada revetmen tidak lebih dari 2,64 tinggi gelombang, $\mathrm{HmO}$.
\end{abstract}

Kata Kunci: Revetmen, buis beton, rayapan gelombang, model fisik 


\section{PENDAHULUAN}

Salah satu struktur pantai yang digunakan untuk menanggulangi erosi adalah struktur revetmen. Umumnya struktur ini diletakkan untuk memberikan perlindungan pada pantai dari gelombang dan arus. Secara umum, CERC (1973) mengklasifikasikan revetmen menjadi dua tipe yakni revetmen yang kaku dan tertanam di satu tempat dan revetmen yang berupa susunan unit armor. USACE (2006) merangkum beberapa jenis revetmen yang umum di Amerika Serikat seperti quarry stone, gabions, fieldstone, concrete, bags, vegetation, concrete armor unit, concrete revetment blocks, concrete-filled mattress, concrete slabs dan landing mat. Di Indonesia, tipe revetmen yang umum ditemui adalah revetmen buis beton. Buis beton merupakan sebuah teknologi konstruksi berupa material beton pracetak. Teknologi ini juga sudah sering diterapkan dalam pembuatan sumur maupun gorong-gorong untuk saluran air. Buis beton yang digunakan untuk struktur revetmen umumnya berbentuk silinder pipih. Setiap unit buis beton disusun sedemikian rupa untuk membentuk tangga bertingkat dengan kemiringan (slope) sesuai kebutuhan desain perlindungan pantai.

Dalam penerapannya, masa pakai revetmen seringkali berkurang disebabkan oleh interaksi hidrodinamis struktur dengan gelombang dan arus. Masalah yang sering ditimbulkan oleh arus pada revetmen adalah gerusan (scour) pada kaki struktur. Di sisi lain, gelombang juga menimbulkan masalah struktur dalam bentuk rayapan gelombang (run up) dan limpasan gelombang (overtopping).
Ketika gelombang menjalar dan mendekati struktur, energi gelombang yang berinteraksi dengan struktur ditransfer menjadi pecahnya gelombang, refleksi gelombang dan rayapan gelombang (Massie,1976). Rayapan gelombang terjadi karena adanya transfer momentum saat gelombang menghantam struktur revetmen. Diskusi pada makalah ini hanya berfokus pada rayapan gelombang.

Run up $(R u)$ dapat didefenisikan sebagai jarak vertikal antara SWL (Still Water Level) dengan titik tertinggi pada slope yang dicapai oleh air yang merayap. SWL merupakan rata-rata muka yang memperhitungkan efek pasang surut dan wind set up. Gambar 1 menunjukkan sketsa sederhana dari rayapan gelombang pada slope struktur revetmen. Rayapan gelombang bergantung pada beberapa faktor seperti arah datang gelombang, geometri struktur dan slope roughness (Molenaar dan Voorendt, 2016).

Meskipun sudah sering digunakan di Indonesia, desain revetmen buis beton masih belum memiliki standar baku untuk perhitungan rayapan gelombang. Oleh karena itu, penelitian ini diperlukan untuk merancang standar baku desain revetmen buis beton sebagai solusi terhadap permasalahan tersebut. Secara khusus, makalah ini fokus membahas rayapan gelombang pada revetmen buis beton. Uji model fisik dilakukan untuk mengetahui hubungan rayapan gelombang dengan struktur revetmen buis beton.

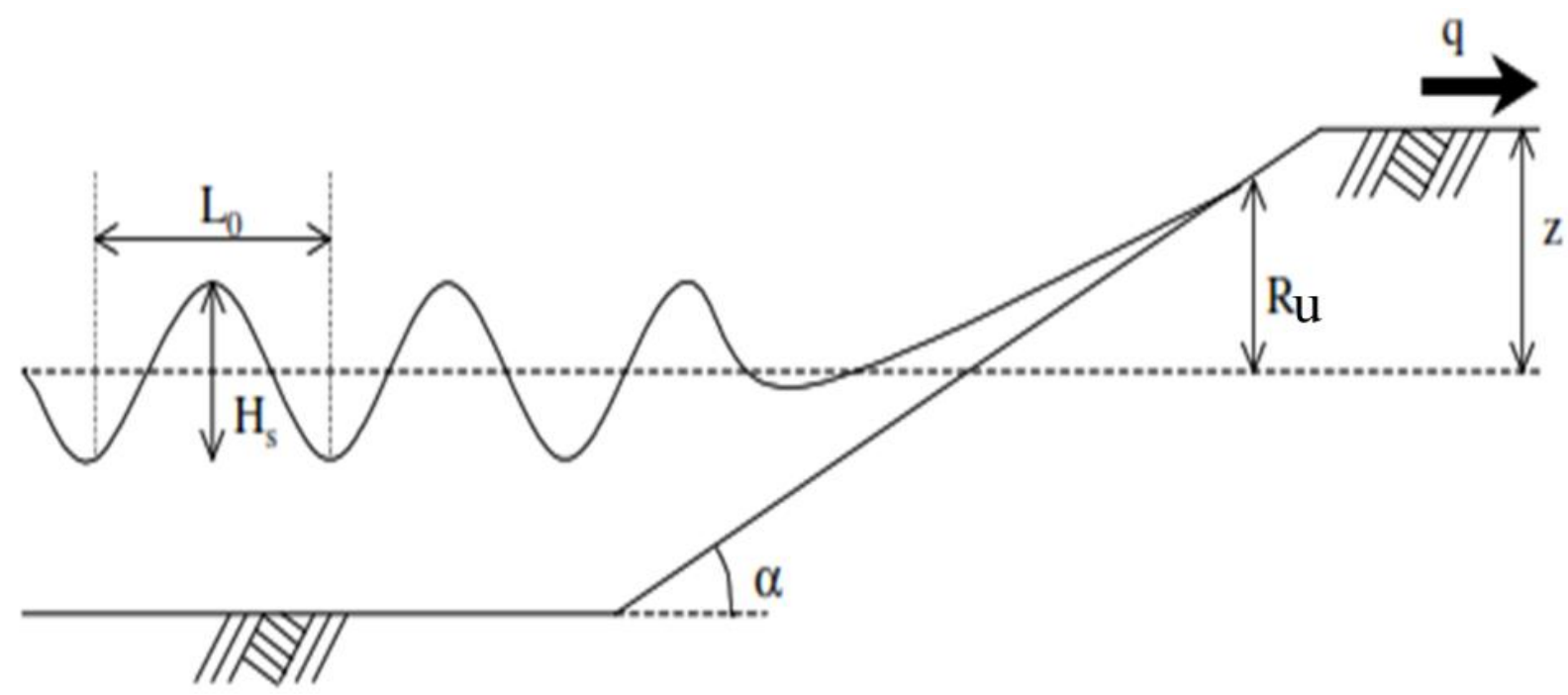

Gambar 1 Sketsa Rayapan Gelombang pada Slope Revetmen (Molenaar dan Voorendt,2016) 


\section{METODOLOGI}

Penelitian ini dilakukan secara eksperimental di Laboratorium Balai Penelitian dan Pengembangan Pantai, Kabupaten Buleleng, Provinsi Bali, Indonesia. Uji model fisik revetmen buis beton ini menggunakan skala geometrik 1:10 pada kolam saluran gelombang (wave flume) piston multi-segmen yang dapat membangkitkan gelombang reguler maupun acak. Saluran gelombang (wave flume) memiliki ukuran $40 \mathrm{~m} \mathrm{x}$ $3 \mathrm{~m}$. Elevasi muka air diukur menggunakan instrumen wave probe. Data elevasi ini kemudian diolah menjadi parameter gelombang seperti tinggi gelombang $(\mathrm{H})$ dan periode gelombang (T). Penentuan jarak peletakan antar wave probe mengacu pada hasil percobaan yang dilakukan oleh Mansard \& Funke (1980).

Uji model fisik revetmen buis beton dijalankan berdasarkan skenario yang terdapat pada Tabel 1 . Simulasi dilakukan pada wave flume dengan kedalaman $0,45 \mathrm{~m}$. Model revetmen buis beton disiapkan dengan parameter desain: pada susunan buis beton $(\theta)$, ketinggian struktur (L), diameter buis beton $(\varphi)$. Revetmen kemudian diuji dengan gelombang reguler dengan variasi tinggi gelombang
(10 dan $15 \mathrm{~cm}$ ) dan variasi periode gelombang $(2,5$ dan $3 \mathrm{~s}$ ). Total ada 36 skenario uji gelombang.

Tabel 1 Skenario Uji Model Fisik Revetmen Buis Beton

\begin{tabular}{l|l|c|c}
\hline No. & \multicolumn{1}{|c|}{ Variabel } & Simbol & Variasi \\
\hline 1 & Tinggi gelombang datang & $\mathrm{Hi}(\mathrm{m})$ & 0,$15 ; 0,10$ \\
2 & Periode gelombang & $\mathrm{T}(\mathrm{s})$ & 2,$5 ; 3$ \\
3 & $\begin{array}{l}\text { Perbandingan ketinggian } \\
\text { buis beton dengan }\end{array}$ & $\mathrm{L} \phi$ & 0,$33 ; 0,5 ;$ \\
& $\begin{array}{l}\text { diameter } \\
4\end{array}$ & & 0,6 \\
& Kemiringan Buis beton & $\theta\left(^{\circ}\right)$ & $45 ; 33 ; 63$ \\
\hline
\end{tabular}

Penyusun buis beton pada model fisik ini disusun dalam satu kesatuan unit armor (Gambar 2). Desain ini dilakukan dalam satu kesatuan tanpa memperhatikan berat dari armor tersebut. Peletakan model fisik ini juga dilakukan dengan membuat lantai kerja pada saluran flume kaca yang ada di Balai Litbang Pantai. Selain itu di depan struktur revetmen buis ini juga diberikan pasir di depan struktur buis beton tersebut untuk melihat pengaruh dari gerusan kaki pada struktur (Gambar 3).

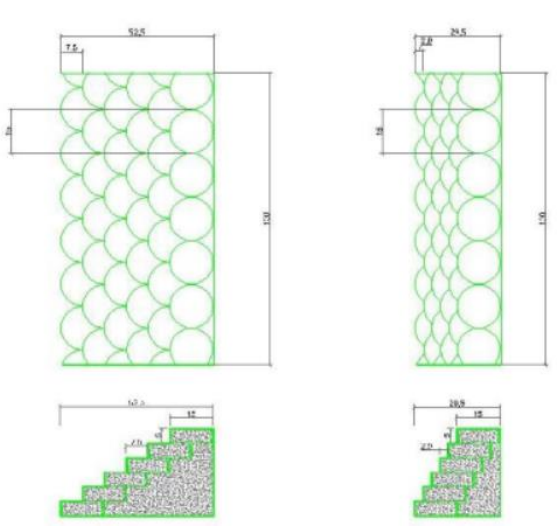

Gambar 2 tampak atas dan tampak samping untuk skenario $L / \phi=0,33$

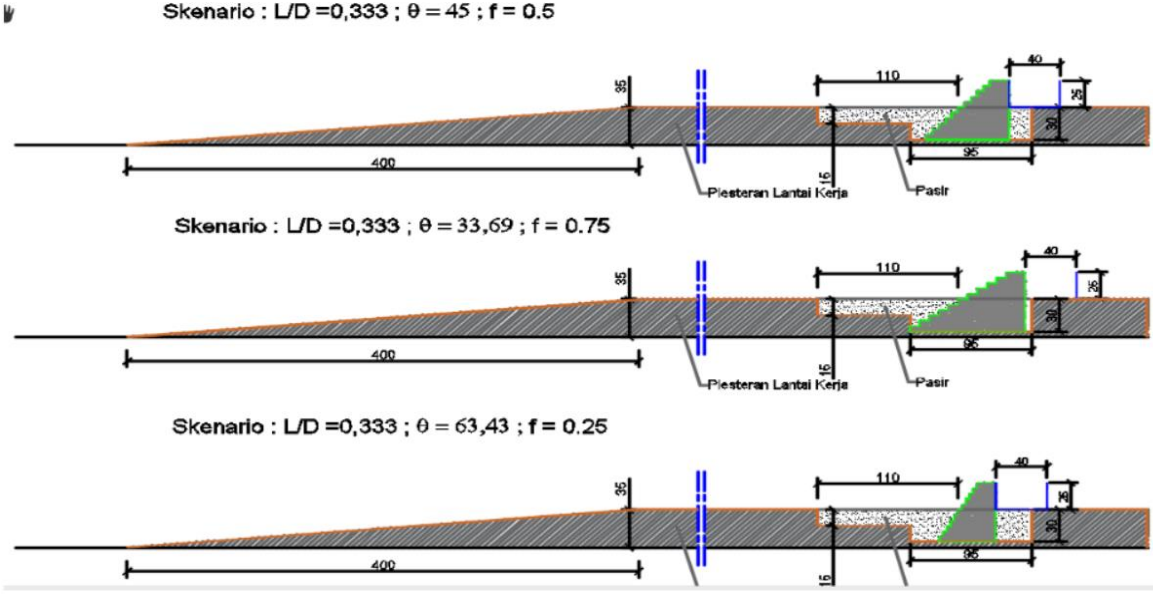

Gambar 3 Skema pengujian untuk skenario $L / \phi=0,33$ 


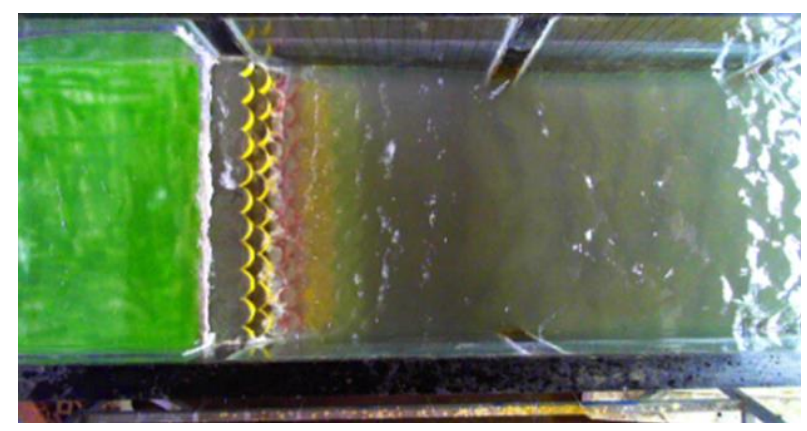

Tampak atas

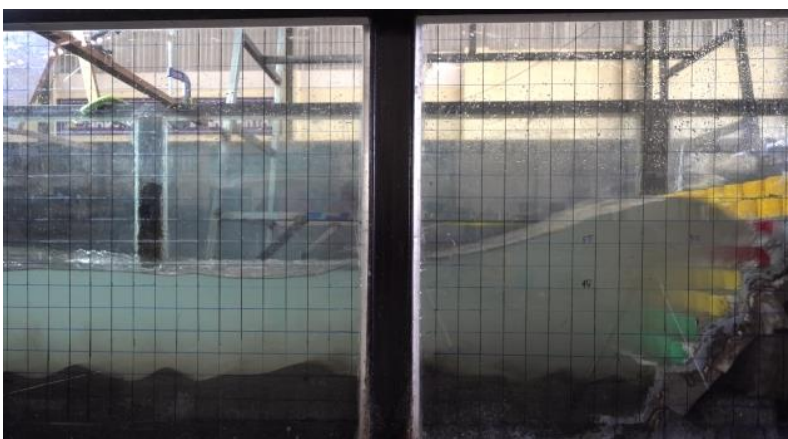

Tampak Samping

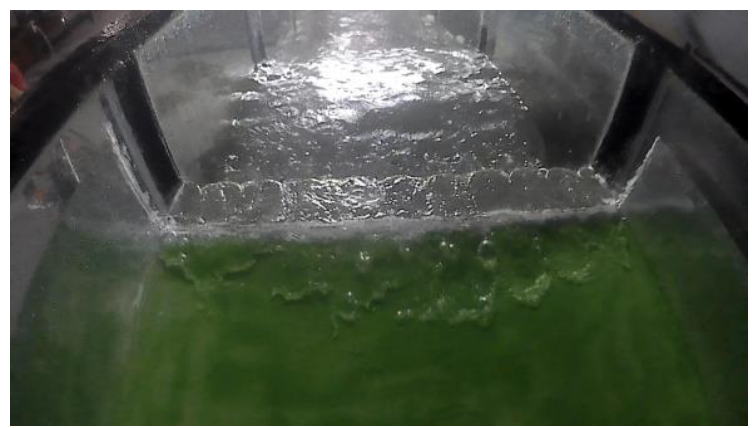

Tampak Belakang

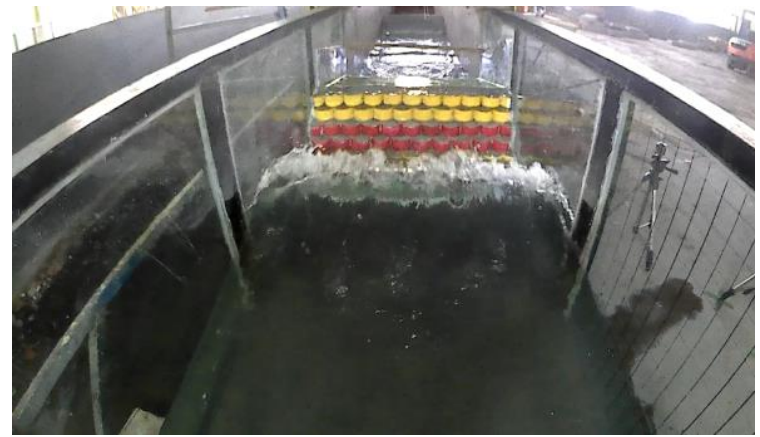

Tampak Depan

Gambar 4 Cuplikan gambar dari video rekaman yang diamati pada pengujian

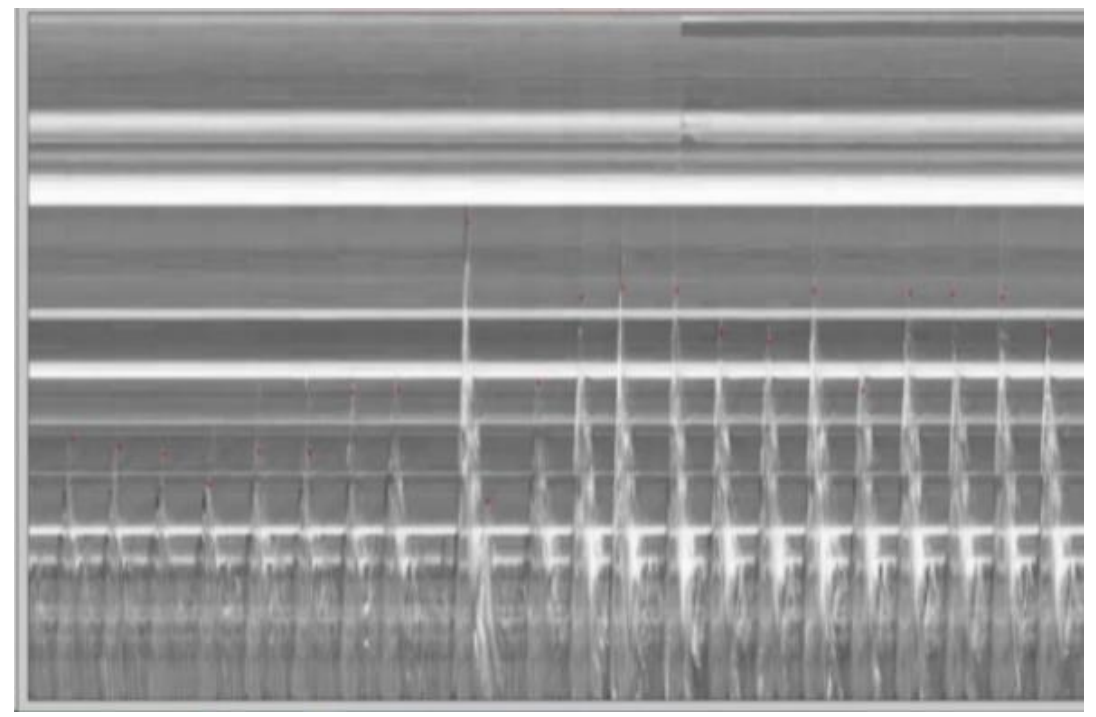

Gambar 5 Citra diekstrak dari video rekaman pengujian revetmen buis beton

Pengamatan pada pengujian ini menggunakan empat video recorder yang dilakukan untuk menangkap ketinggian gelombang, berapa kali kejadian overtopping, gerusan pada kaki struktur, ketinggian gelombang pada tingkatan buis beton dan rayapan gelombang (Gambar 4). Video image yang digunakan analisis rayapan gelombang dengan metode time stack images processing adalah video dari tampak atas.Observasi rayapan gelombang dilakukan dengan menggunakan bantuan kamera video berkemampuan 30 frame per second (fps). Rayapan gelombang diamati dengan kamera tampak atas sepanjang 5 menit. Dari video tersebut, 9000 frame gambar diekstrak dan diolah menggunakan metode time stack images processing yang dikembangkan oleh Schimmels et al. (2012). Hasil gambar yang sudah diolah ditunjukkan pada Gambar 5. Setiap frame gambar tersebut kemudian diamati ketinggian gelombang yang terjadi dengan melakukan pemotongan (transect) di tengah 
struktur. Dengan asumsi bahwa semua ketinggian gelombang di sepanjang struktur sama, frame tersebut dikumpulkan dalam satu gambar yang kemudian diekstrak lagi dengan menggunakan skrip MATLAB dari Doke (2016). Hasil observasi kemudian disajikan untuk perhitungan lebih lanjut seperti pada Gambar 5. Pola gambar hitam putih mewakili titik yang menunjukkan pola rayapan gelombang pada revetmen Buis Beton. Deretan pola yang berbentuk segitiga dengan tinggi yang berbeda menunjukkan tinggi rayapan gelombang pada setiap lapisan buis beton.

Hasil pengolahan data seperti yang ditunjukkan pada Gambar 6 menunjukkan bagaimana rayapan gelombang selama pengujian untuk setiap skenario. Warna pada data rayapan gelombang merupakan interpretasi dari warna ketinggian buis beton dari permukaan air (Ga,bar 7). Dari sini, tinggi rayapan gelombang maksimum $\mathrm{Ru})$ dapat dihitung. Dalam perhitungan, tinggi rayapan gelombang sering dinyatakan sebagai $\mathrm{Ru}{ }_{2} \%$. Alasan penggunaan $\mathrm{Ru}_{2 \%}$ ini dijelaskan secara detail oleh Eurotop (2018). Secara umum, rayapan gelombang secara matematis dinyatakan oleh Hunt (1959) sebagai:

$\frac{\mathrm{Ru}}{H_{S}}=f . \xi$

dengan :

$$
\begin{aligned}
\mathrm{Ru} & =\text { tinggi rayapan gelombang }(\mathrm{m}) \\
\mathrm{H}_{\mathrm{s}} & =\text { tinggi gelombang signifikan }(\mathrm{m}) \\
f & =\text { koefisien rayapan gelombang } \\
\xi & =\text { Bilangan Iribarren }
\end{aligned}
$$

Bilangan Iribarren secara matematis dinyatakan sebagai:

$\xi=\frac{\tan \alpha}{\sqrt{H_{S} / L}}$

dengan:

$$
\begin{array}{ll}
\alpha & =\text { Kemiringan revetmen } \\
\mathrm{L} & =\text { Panjang gelombang }(\mathrm{m})
\end{array}
$$

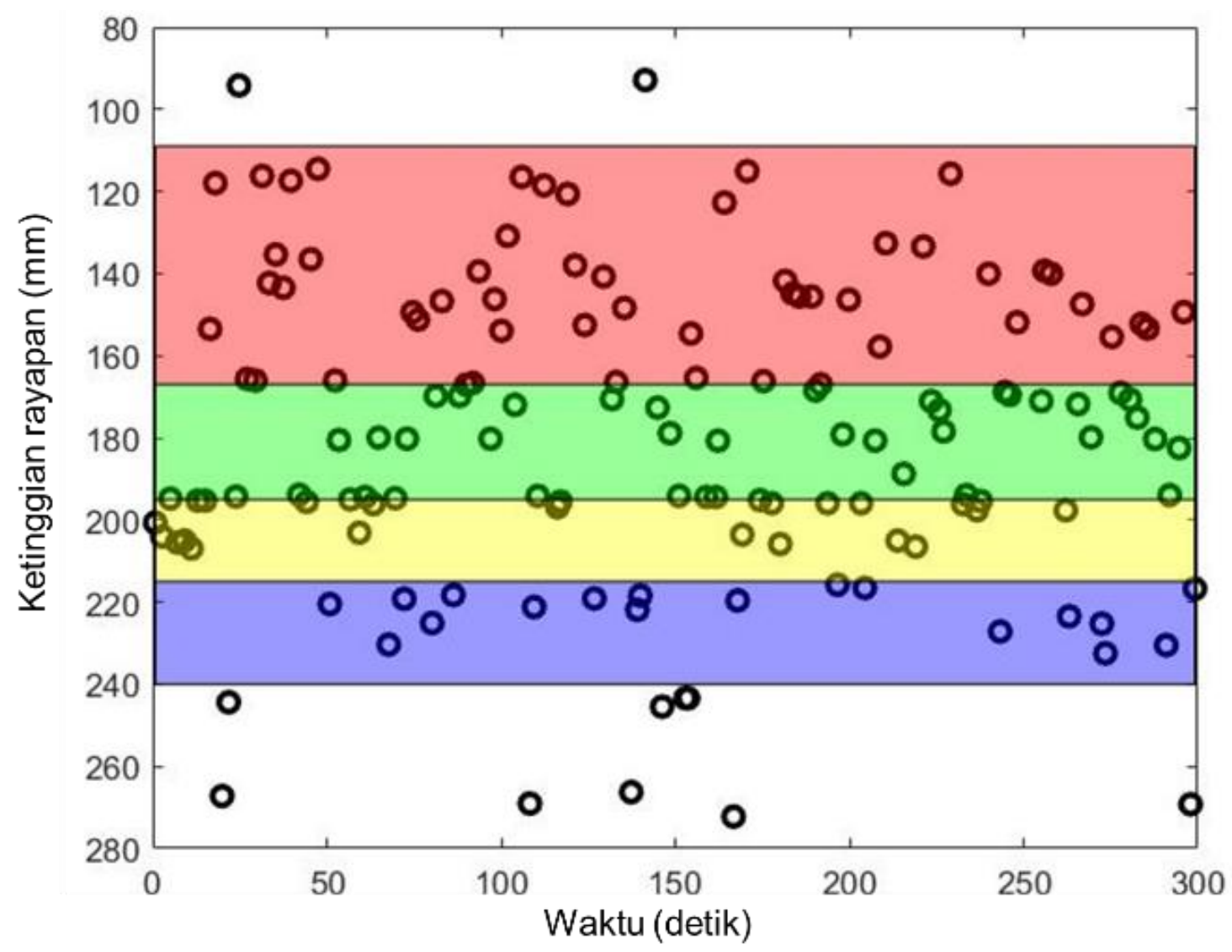

Gambar 6 Data rayapan gelombang dalam visualisasi sederhana 


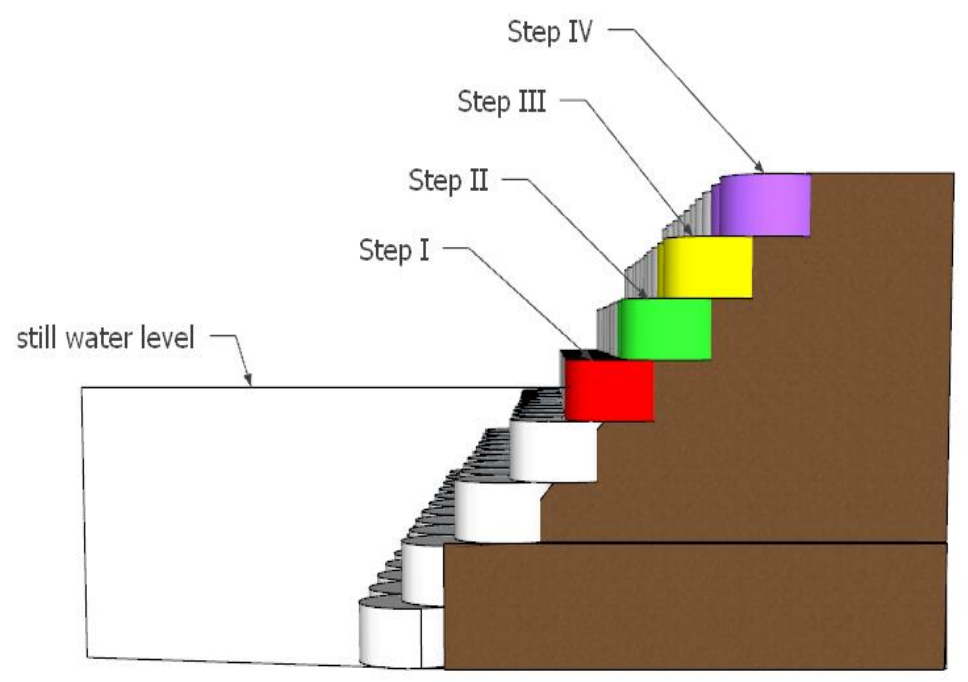

Gambar $\mathbf{7}$ interpretasi warna pada data rayapan gelombang

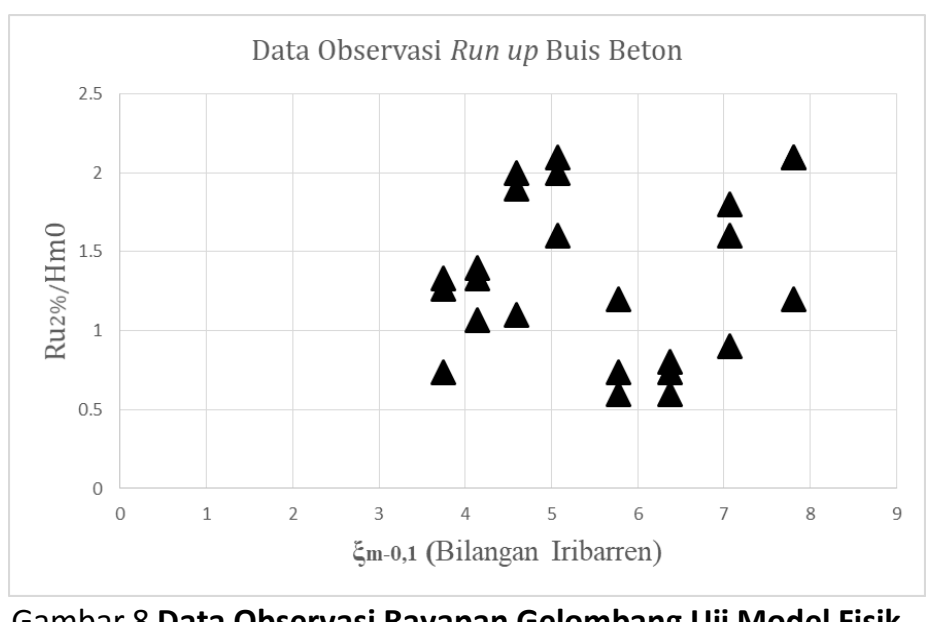

\section{HASIL DAN PEMBAHASAN}

Hasil uji model fisik untuk interaksi rayapan gelombang dan struktur revetmen ditunjukkan pada Gambar 8. Data observasi tersebar pada kisaran bilangan Iribarren $(3,7-7,8)$ dan kisaran $\mathrm{Ru}_{2 \%}$ relatif $(0,6-2,1)$. Dari 36 skenario pengujian, ada sekitar 12 skenario dimana terjadi overtopping atau limpasan gelombang. Oleh karena itu, data yang ditampilkan hanya sebanyak $n=24$ dimana keseluruhan data observasi merepresentasikan interaksi gelombang-struktur dalam hal rayapan gelombang saja. Dengan kata lain, data pengujian dimana terjadi limpasan gelombang tidak ditampilkan. Distribusi data observasi tersebut tidak menunjukkan hubungan linier antara parameter rayapan gelombang relatif $\left(\mathrm{Ru}_{2 \%} / \mathrm{Hm} 0\right)$ dengan Bilangan Iribarren $\left(\xi_{m-1,0}\right)$. Nilai $\mathrm{R}^{2}$ juga tidak menunjukkan hubungan yang signifikan $(=0,0079)$. Namun, analisis lebih lanjut diperlukan untuk memahami interaksi rayapan gelombang dengan struktur revetmen.

Analisis lanjutan dapat dilakukan dengan membandingkan data observasi revetmen buis beton dengan rangkuman data observasi rayapan gelombang dari berbagai penelitian terdahulu yang dirangkum oleh Eurotop (2018). Gambar 9 menunjukkan data uji model fisik rayapan gelombang untuk slope revetmen yang relatif landai. Grafik tersebut menunjukkan bahwa rayapan gelombang relatif memiliki hubungan fungsi reciprocal terhadap parameter Bilangan Iribarren. Grafik rayapan gelombang relatif revetmen Buis Beton diasumsikan memiliki pola hubungan yang sama. Dari sini, analisis regresi untuk menemukan hubungan linier antara kedua parameter tersebut bisa dilakukan. 


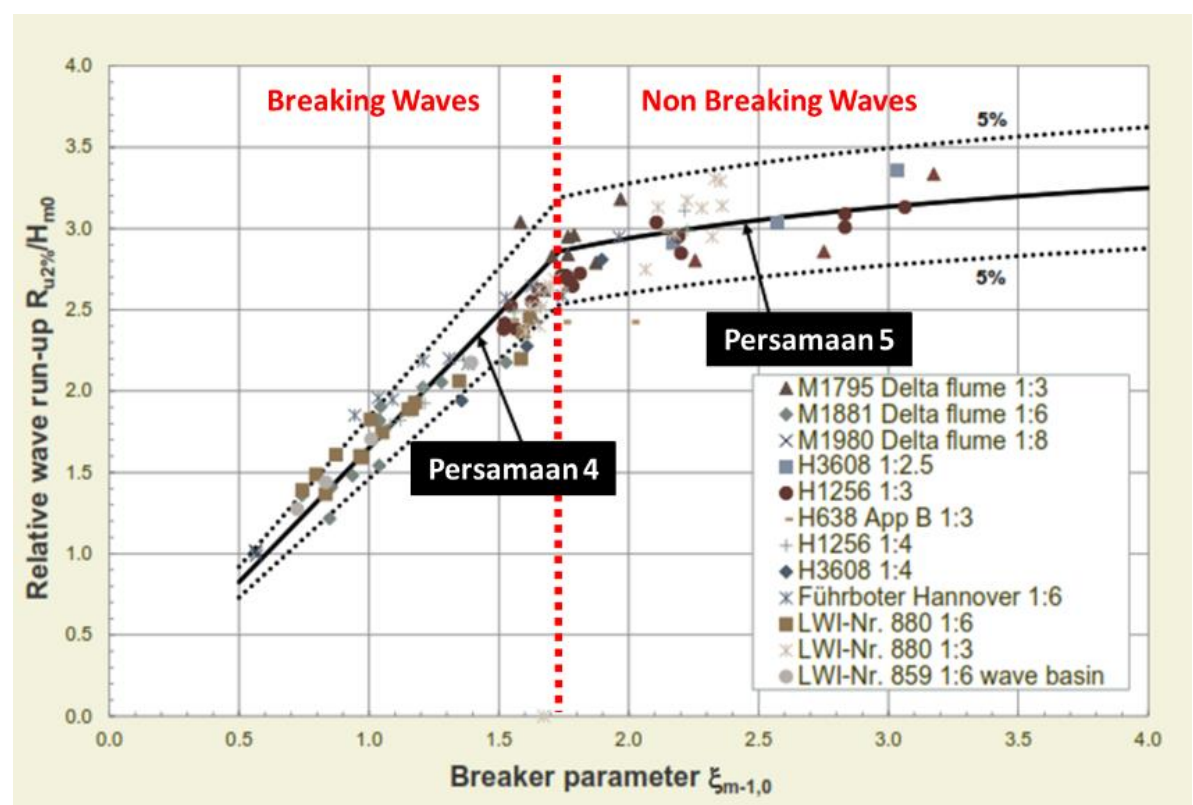

Gambar 9 Rangkuman Data Observasi Rayapan Gelombang Uji Model Fisik (Eurotop,2018)

Van der Weel (2002) yang ditulis ulang dalam Eurotop (2018) menguraikan hubungan reciprocal tersebut menjadi dua persamaan sebagai berikut:

$\frac{\mathrm{R}_{\mathrm{u} 2 \%}}{H_{m 0}}=1.65 * \gamma_{b} * \gamma_{f} * \gamma_{\beta} * \xi_{m-1,0}$

$\frac{\mathrm{R}_{\mathrm{u} 2 \%}}{H_{m 0}}=1.0 * \gamma_{\beta} * \gamma_{f}\left(4-\frac{1,5}{\sqrt{\gamma_{b} * \xi_{m-1,0}}}\right)$

dengan:

$\gamma_{b}$ adalah koefisien rayapan gelombang untuk pengaruh berm (geometri struktur).

$\gamma_{f}$ adalah koefisien rayapan gelombang untuk pengaruh slope roughness.

$\gamma_{\beta}$ adalah koefisien rayapan gelombang untuk pengaruh sudut datang gelombang.

Persamaan 4 mendeskripsikan hubungan linier $(\mathrm{y}=\mathrm{x})$ rayapan gelombang relatif $\left(\frac{\mathrm{R}_{\mathrm{u} 2 \%}}{H_{m 0}}\right)$ untuk zona breaking waves. Sebaliknya, persamaan 5 menunjukkan hubungan reciprocal $(\mathrm{y}=1 / \mathrm{x})$ untuk rayapan gelombang pada zona non breaking wave. Jika melihat distribusi data rayapan gelombang relatif revetmen buis beton, data tersebar di zona non breaking wave. Selain itu, pengamatan di laboratorium menunjukkan energi gelombang datang tidak terdisipasi melalui pecahnya gelombang melainkan melalui refleksi gelombang, rayapan gelombang dan untuk kasus tertentu, limpasan gelombang (Gambar 10). Dengan kata lain, rumus empirik rayapan gelombang untuk revetmen buis beton seharusnya memiliki bentuk hubungan seperti persamaan 5 .

Hubungan rayapan gelombang relatif terhadap parameter Bilangan Iribarren diasumsikan bersifat repicrocal (Gambar 11). Fungsi repicrocal secara matematis dapat dinyatakan sebagai berikut:

$y=\beta_{0}+\beta_{1}\left(\frac{1}{x}\right)$

Hubungan ini terlihat jelas pada grafik rayapan relatif Eurotop (2018) pada Gambar 9. Akan tetapi, hubungan tersebut tidak terlihat jelas pada data observasi rayapan gelobang revetmen buis beton karena ketidaktersediaan data pada zona breaking wave (Gambar 8).

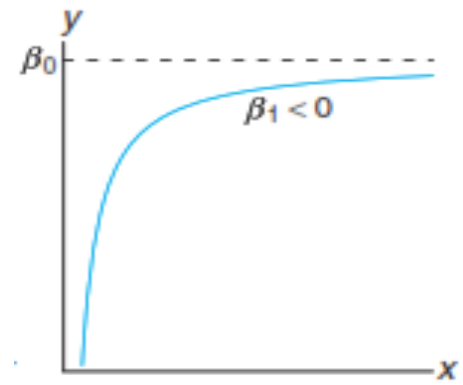

Gambar 10 Fungsi repicrocal (Walpole et al,2016) 


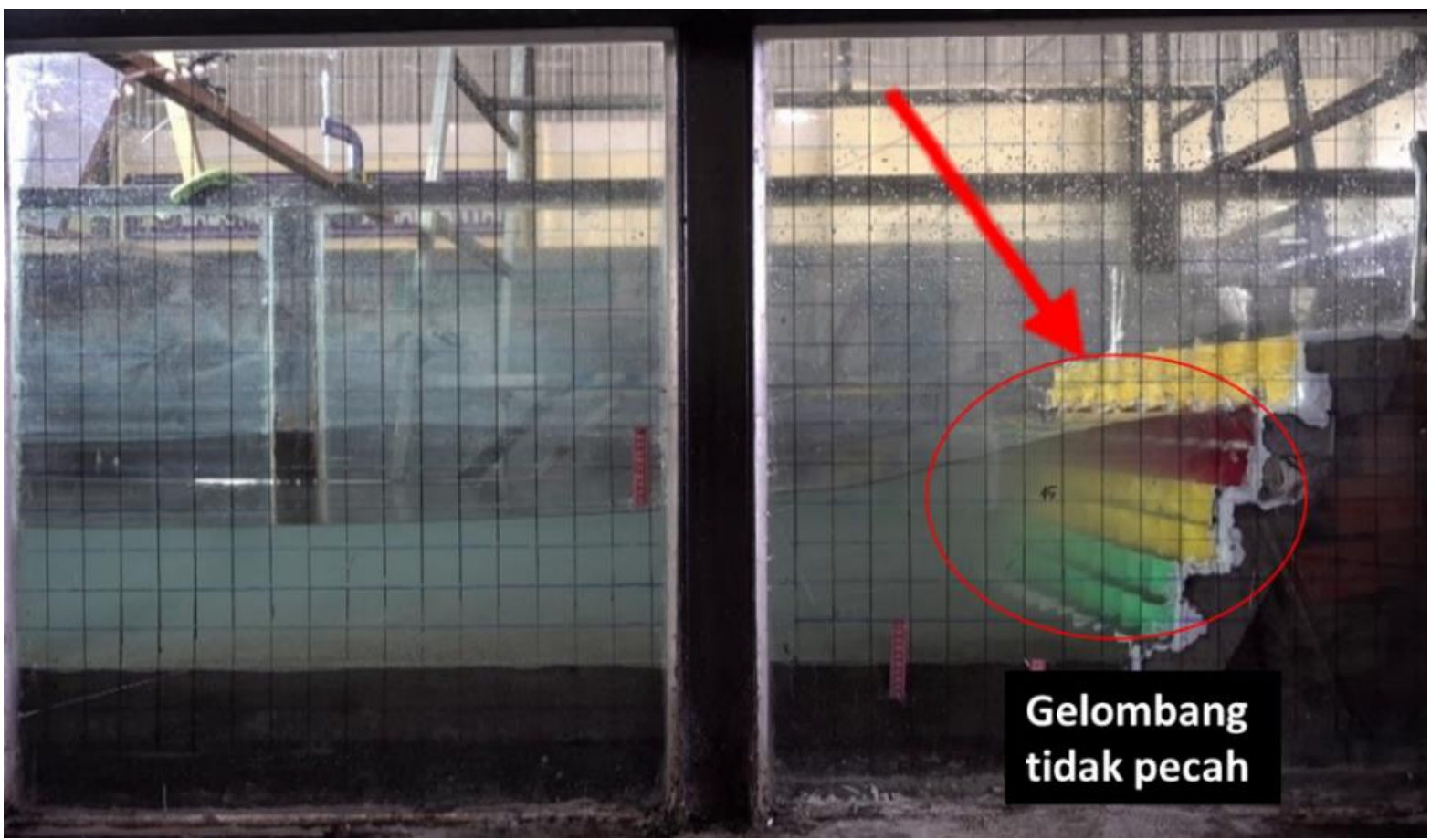

Gambar 11 Rayapan (run-up) Gelombang Saat Simulasi Uji Model

Walpole et al (2017) menyarankan untuk melakukan transformasi pada fungsi yang bersifat repicrocal. Hubungan regresi yang dicari adalah antara y dengan $x^{*}=1 / x$. Dengan sedikit modifikasi yang mengikuti persamaan 5 , hubungan antara rayapan gelombang relatif pada revetmen buis beton dapat dicari dengan melakukan regresi antara $y=\frac{\mathrm{R}_{\mathrm{u} 2 \%}}{H_{m 0}}$ dengan $\mathrm{x}^{*}=\frac{1}{\sqrt{\xi_{m-1,0}}}$.

Dengan melakukan analisis regresi antara $y=\frac{\mathrm{R}_{\mathrm{u} 2 \%}}{H_{m 0}}$ dengan $\mathrm{x}^{*}=\frac{1}{\sqrt{\xi_{m-1,0}}}$, hubungan rayapan gelombang relatif terhadap Bilangan Iribarren dapat diperoleh sebagai berikut:

$\frac{\mathrm{R}_{\mathrm{u} 2 \%}}{H_{m 0}}=\left(3-\frac{4}{\sqrt{\xi_{m-1,0}}}\right)$

Persamaan 7 tergambar dalam grafik padaGambar 12. Persamaan tersebut belum lengkap jika dibandingkan dengan Persamaan 5. Dalam hal revetmen buis beton, koefisien rayapan gelombang $\gamma_{b}$ dan $\gamma_{\beta}$ dapat diabaikan karena revetmen buis beton tidak memiliki berm dan arah datang gelombang dalam wave flume adalah tegak lurus. Koefisien rayapan yang perlu dimasukkan adalah $\gamma_{f}$. Karena buis beton terbuat dari beton, koefisien $\gamma_{f}$ diasumsikan bernilai 0,9 sesuai acuan Eurotop (2018). Dari sini, mean value dari hubungan kedua parameter tersebut adalah 1,205 dengan standar deviasi adalah 0,465. Menggunakan istilah Eurotop
(2018), persamaan mean value approach untuk hubungan rayapan gelombang relatif pada revetmen buis beton adalah sebagai berikut:

$\frac{\mathrm{R}_{\mathrm{u} 2 \%}}{H_{m 0}}=1.205 * \gamma_{f}\left(3-\frac{4}{\sqrt{\xi_{m-1,0}}}\right)$

dengan :

$\gamma_{f}$ adalah koefisien rayapan gelombang slope roughness $(=0,9)$.

Dari hasil sebaran data observasi rayapan gelombang pada revetmen buis beton disertai plot Persamaan 8 dan selang kepercayaan sebesar 90\% Gambar 13. Grafikini menunjukkan bahwa sebagian besar data uji model fisik masuk dalam selang kepercayaan. Hanya ada sekitar $n=3$ data yang berada di luar selang kepercayaan. Mengacu pada Eurotop (2018), persamaan 8 yang masih merupakan persamaan stokastik dapat ditulis kembali sebagai :

$\frac{\mathrm{R}_{\mathrm{u} 2 \%}}{H_{m 0}}=1,67 * \gamma_{f}\left(3-\frac{4}{\sqrt{\xi_{m-1,0}}}\right)$

Nilai 1,67 merupakan penjumlahan dari mean value $=1,205$ ditambah dengan nilai standar deviasi $(=0,465)$. Jika dilihat dari grafik pada Error! Reference source not found., rayapan gelombang seharusnya tidak lebih dari 2,64 Hm0. 


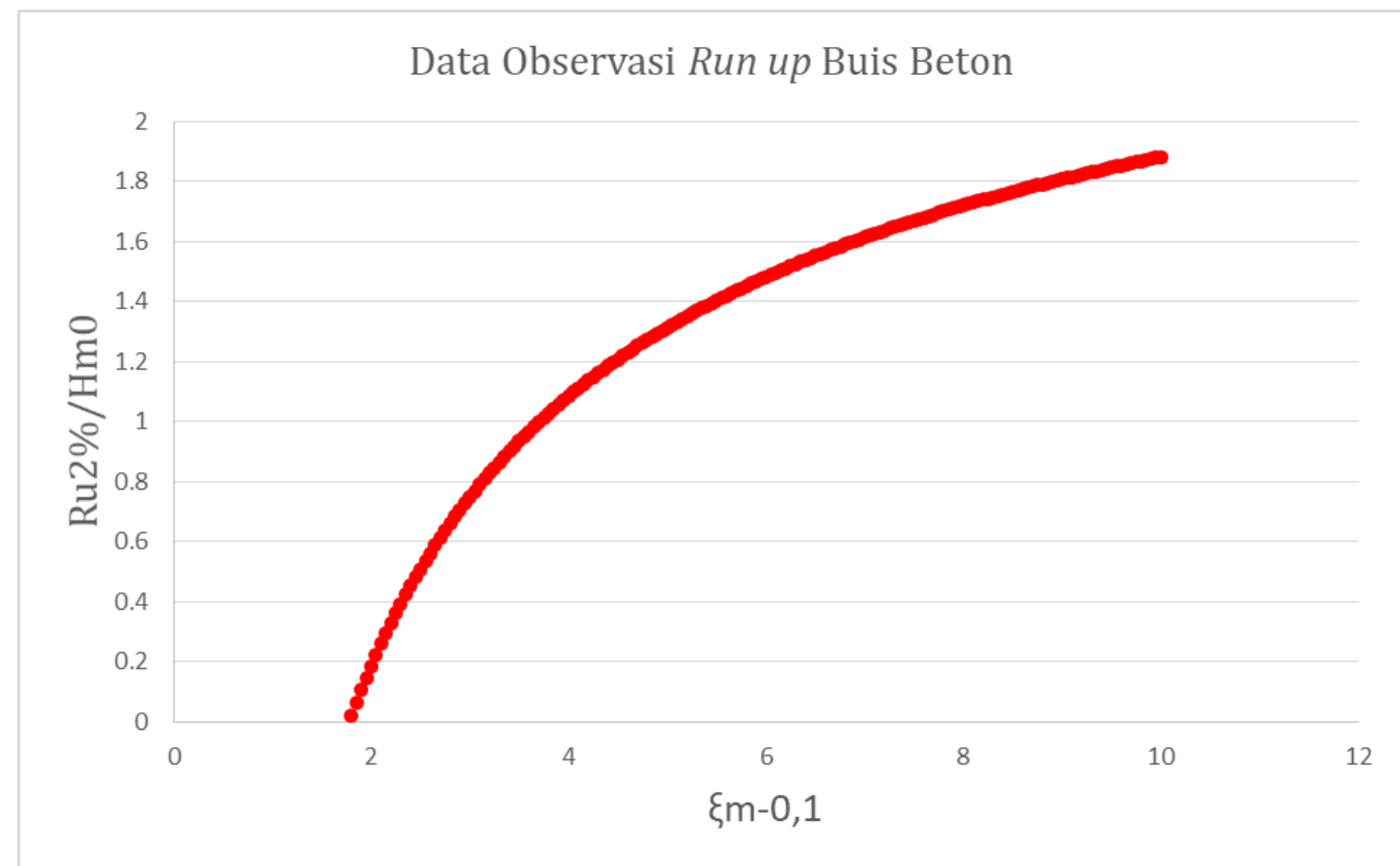

Gambar 12 Hubungan Repicropal Antara $\frac{\mathrm{R}_{\mathrm{u} 2 \%}}{H_{m 0}}$ dengan $\xi_{m-1,0}$

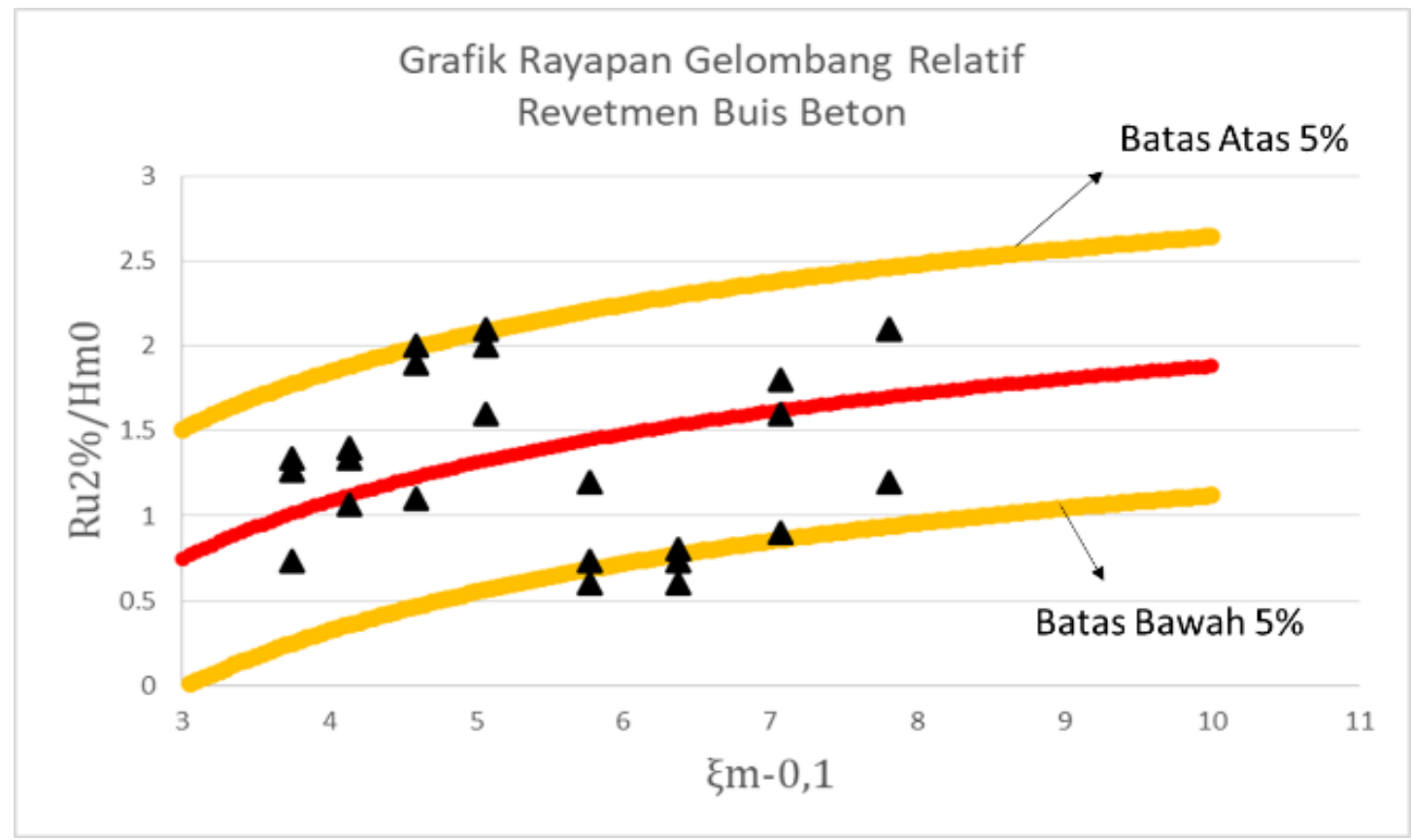

Gambar 13 Persaman Rayapan Gelombang Relatif pada Revetmen Buis Beton (dengan Data Observasi dan Selang Kepercayaan 90\%)

\section{KESIMPULAN DAN SARAN}

Hubungan rayapan gelombang relatif $\left(\frac{\mathrm{R}_{\mathrm{u} 2 \%}}{H_{m 0}}\right)$ dengan parameter Bilangan Iribarren $\left(\xi_{m-1,0}\right)$ memiliki hubungan reciprocal. Meskipun tidak tersedia data rayapan gelombang pada zona breaking wave, hubungan ini dapat diasumsikan reciprocal jika membandingkan data observasi dengan data uji model fisik dari penelitian- penelitian sebelumnya yang dirangkum oleh Eurotop (2018). Hasil penelitian menunjukkan bahwa rayapan gelombang secara umum tidak lebih dari 2,64 Hm0.

Untuk meningkatkan akurasi persamaan rayapan gelombang relatif untuk revetmen buis beton, uji model fisik perlu dilakukan untuk menghitung slope roughness. 


\section{UCAPAN TERIMA KASIH}

Terimakasih kepada semua pihak yang telah membantu terutama rekan-rekan teknisi Laboratorium Balai Penelitian dan Pengembangan Pantai dalam pelaksanaan kegiatan Model Fisik Revetmen Menggunakan Buis Beton.

\section{DAFTAR PUSTAKA}

Coastal Engineering Research Center (U.S.). (1973). Shore Protection Manual.Vol.2. Fort Belvoir, Va. U.S Army Coastal Engineering Research Center.

Doke, J. (2016). Matlab Script : GRABIT Extracts data points from an image file. (https://www.mathworks.com/matlabcentral Lfileexchange/7173-grabit), MATLAB Central File Exchange. Diambil November 30, 2018.

Eurotop. (2018). Manual on Wave overtopping on Sea Defences and Related Structures. Retrieved from www.overtopping-manual.com

Hunt, I. A. (1959). Design of Seawalls and Breakwaters. J.Waterw. Harbors Division ASCE 85,123-152

Mansard, E. \& Funke, E. (1980) The measurements of incident and reflected spectra using a least squares method. Coastal Engineering Proceedings, 1(17), 8. https://doi.org/10.9753/icce.v17.8

Molenaar, W.F \& Voreendt, M.Z. (2016). Manual Hydraulic Structure. Delft: Technical University Delft.
Massie, W.W. (1976). Introduction to Coastal Engineering. Vol.3. Delft: Technical University Delft.

http://resolver.tudelft.nl/uuid:010a725cc507-4107-b5ee-0ec64aab2f42

Schimmels, S., Vousdoukas, M.I., Wziatek, D., Becker, K., Gier, F., \& Oumeraci, H. (2012). Wave Runup Observations on Revetments with Different Porosities. Coastal Engineering Proceedings 1(33).

https://doi.org/10.9753/icce.v33.structures.7 $\underline{3}$

Eslami, A.S \& Van Gent, M. R. (2010). Wave overtopping and rubble mound stability under combined loading of waves and current. Coastal Engineering Proceedings, 1(32).https://doi.org/10.9753/icce.v32.struct ures.12

United States Army Corps of Engineering (USACE). (2006). Coastal Engineering Manual. Washington, D.C.: U.S Army Corps of Engineers.

Van Der Weel, J.W. (2002). Technical Report on Wave Run up and Overtoppingat Dikes. Delft: Technical Advisory Committee on Flood Defence, The Netherland.

Walpole, R.E., Myers, R.H., Myers, S.L., \& Ye, K. (2016). Probability and Statistics for Engineers and Scientists. Italy: Pearson. 